\title{
THE INCLUSIVE TEACHER - ALTERNATIVE ROUTES FOR TEACHER IN THE FIELD OF INCLUSIVE EDUCATION. A ROMANIAN PERSPECTIVE
}

\author{
Elena MARIN, PhD, \\ University of Bucharest, Faculty of Psychology and Education Sciences, \\ Romania \\ elena.marin@fpse.unibuc.ro
}

\begin{abstract}
To respond to the needs of all students, teachers must have access to a highly qualitative teaching training system that will allow them to get access to the most important and relevant information in the field of education. It is also important for future teachers to receive the proper practicum experience that will prepare them to become the 21 st century teachers. But, in order to be ready to face inclusion in the classroom, teachers must receive the proper training so that they are prepared to teach in an inclusive environment. All teachers must held a set of specific skills, teaching methods and tools so that they become able to provide children with a qualitative learning experience, that has as a main goal to value classroom diversity. That is why, we assume it is necessary to rethink the entire teacher training system in order that all teachers, regarding their specialization, to be properly trained in order to face inclusion in the classroom. The aim of this paper is to briefly present some alternative routes into the initial teacher training and continuing professional development at national level, underlining the advantages and limitation of each proposal according to the Romanian national legislation.
\end{abstract}

Keywords: teacher training, alternative routes, inclusive education, Romania.

\section{Introduction}

In European countries it is important to have well - trained and well informed teachers in order to ensure a workforce that can answer to the current socio-economic requirements. The European Commission states that a high-quality teaching is a prerequisite for high-quality education and training (COM 2007a). Despite this, a Commission to the Council and the 
European Parliament report shows that the teacher training systems currently in place in the Member States do not promote the acquisition of the new teaching skills which have been made necessary by the changes in education and in society in general (COM, 2007b).

To do so, the main focus must shift from a system that values the acquisition of knowledge to a system that aims at developing student's transversal skills, with a strong accent on preparing future teachers to respond to diversity in the classroom. Therefore, the current structure of the national teacher training system needs to be redesigned and should be based on the assumption that improving the quality of teaching staff is the key. Other implications related to this topic refer to the process of attracting and selecting the best candidates for the teaching career, providing a qualitative system for the continuing professional development in order to reinforce teacher competences.

\section{The teacher training system. Romania case study}

In this context, the teacher training system is seen as playing an important role in our current educational system. The interest is on redefining the role of teachers and his qualification in accordance with the new requirements. According to the Romania National Educational Law it is important that Apart from one or several specializations, the teaching staff may acquire didactic competences for the disciplines in the same fundamental area as the graduation area, by training programmes by Government decision" (Romania`s Law of Education, 1/2011 Art. 244 (5)).

The competences needed for the teaching carrier are based on three great competences categories: (Potolea \& Toma, 2013)

1. Special competences - are defined according to National Register of Qualifications in Higher Education (RNCIS) and are published on http://www.rncis.ro;

2. Professional competences - targeting: Design of teaching; Management and monitoring learning; Evaluation of educational activities; Use of the digital technologies; Knowledge of counseling and differential treatment of pupils; Classroom Management;

3. Transversal competences - targeting: Institutional development of the school and school-community partnership; Career Management and Personal Development; Applied Educational Research.

From all the above emerges the idea that all teachers should acquire skills that allows them to provide differentiated support for all children. All teachers must be able to cope with an inclusive educational system. Therefore, the recognition and the respect for diversity and intercultural are linked with the recognition and paying respect for individual differences, emphasizing the need to avoid any kind of discrimination. Teachers must pay 
respect to the principles and to the rules of professional conduct, to promote a responsible attitude towards the teaching activity that must be personalized according to the uniqueness of every pupil. Based on these standards it can be shaped the teacher's profile so that could be in accordance with the professionalization concepts of the teaching career. Păun (2002) claims that the professionalization is a processes of creating a set of skills in a certain domain based on a set of theoretical and practical knowledge.

As Iucu (2001) notes, the initial teacher training system is a stage of transformations and restructurings and can only be in accordance with the future social, cultural, scientific, civic and spiritual values.

The changes occurred in the initial teaching training after the implementation of the Bologna Process brings into attention the restructuring of the initial teacher training system that is being conducted through the University's Teacher Training Departments (TTD), being organized as a concurrent model for initial teacher training.

In Romania, the Teacher Training Departments in universities has undergone a series of changes that aims to:

- introduce the interview as a way of selecting students that enroll in TTD;

- introduce a two level teacher training system in order to achieve the initial teaching training (called Level I and Level II)

- allocate more time, 56 hours instead of 42 , to introduction courses as the course Pedagogy I (The Fundamentals of Pedagogy and the Curriculum Theory and Methodology) and Pedagogy II (Instructional Theory and Evaluation Theory and Methodology);

- introduce new courses such as: Classroom Management and Computer Assisted Education as compulsory subjects;

- introduce the graduation exam at the end of Level I and II.

However, according to the new National Education Law 1/2011, the initial teacher training system is stipulated to no longer be performed by TTDs following the concurrent model that allows the initial teacher training to be conducted along with the specialization training. Therefore, the new pathway into the teaching career must be done following a consecutive model, performed under a didactic master with a two-years-duration. After the graduation of this didactic maser, the new Law of education stipulates that a one-year of practical training, performed in a school under a mentor teacher supervision, is needed to enter the teaching career. Currently, both training systems are fully functional in Romania.

Starting from the changes occurred within the training systems and taking into account the European directives that puts a stress on building inclusive schools and inclusive societies, we come with a set of proposals in order to improve the initial teacher training and the continuing teacher development system. These proposals follow the requirements of a teacher teaching 
system that wants to respect the inclusive education principle. Therefore, by going on with this study, we consider appropriate tart a debate by bringing into attention flexible routes into the teaching training system, highlighting the opportunities and limitations provided by these alternative ways.

\section{Flexible routes into the teacher training. Possible scenarios}

Starting from the assumption that the presence of children with special educational needs is a reality into the Romanian schools, teachers, now more than ever, must be prepared to be ready to teach all children regardless of their learning needs, behavioral, intellectual, emotional and social and physical capacities (Marin, 2014).

That is why, we assume it is necessary to rethink the entire teacher training system in order that all teachers, regarding their specialization, to be properly trained in order to face inclusion in the classroom. In the next chapter the main focus will be on presenting alternative routes into the initial teacher training and continuing professional development at national level.

\subsection{Flexible routes into the initial teacher training for primary and preschool level in the field of inclusive education}

We shall begin by bringing into discussion the teacher training programs for primary and preschool system. Nowadays, the training of pre-school and primary teachers in Romania is achieved through the Pre-school and primary teacher training departments. The curriculum for this programme does not include a course related to inclusive education. This course will allow all students to receive proper training in the field of inclusive education and to be ready to face inclusion in the classroom. The main motivation which stays at the base of this proposal is the importance of the pre-school and primary teachers in every child's life, by influencing pupils to develop a positive attitude towards appreciating diversity, making sure all children learn to appreciate and acknowledge the value of the diversity and to develop the participative skills.

Teachers as main promoters for diversity have the task to respect students special educational needs, emphasizing the right that every child should have, the right to be seen as an active participant into the educational process, as a person and a member with equal rights within the community and within society. The primary and preschool teachers have a very important role in the development of children's personality that is why all future teachers must be thoroughly prepared to face inclusiveness in the classroom.

All in all, introducing Inclusive education course within the pre-school and primary teacher training system, can allow future teachers acquire knowledge, becoming familiar with the specific terminology of inclusive 
education. They can also develop a positive attitude towards inclusiveness and the practice of inclusive education.

\subsection{Flexible routes into the initial teacher training for secondary and high school level in the field of inclusive education}

In the following pages there are presented three different routes into the initial teacher training for secondary and high school level.

Within the first proposal, Progressive Route 1, the teacher training system follows the consecutive model. We suggest the insertion of the study course Inclusive Education among the four other primary study courses. Thus in addition to the four fundamental pedagogical training study courses: Educational Psychology, Pedagogy I (Fundamentals of Pedagogy and Curriculum Theory), Pedagogy II (Instructional Theory and Evaluation Theory), and Classroom management we recommend to add the Inclusive Education study course as presented in Figure 1.

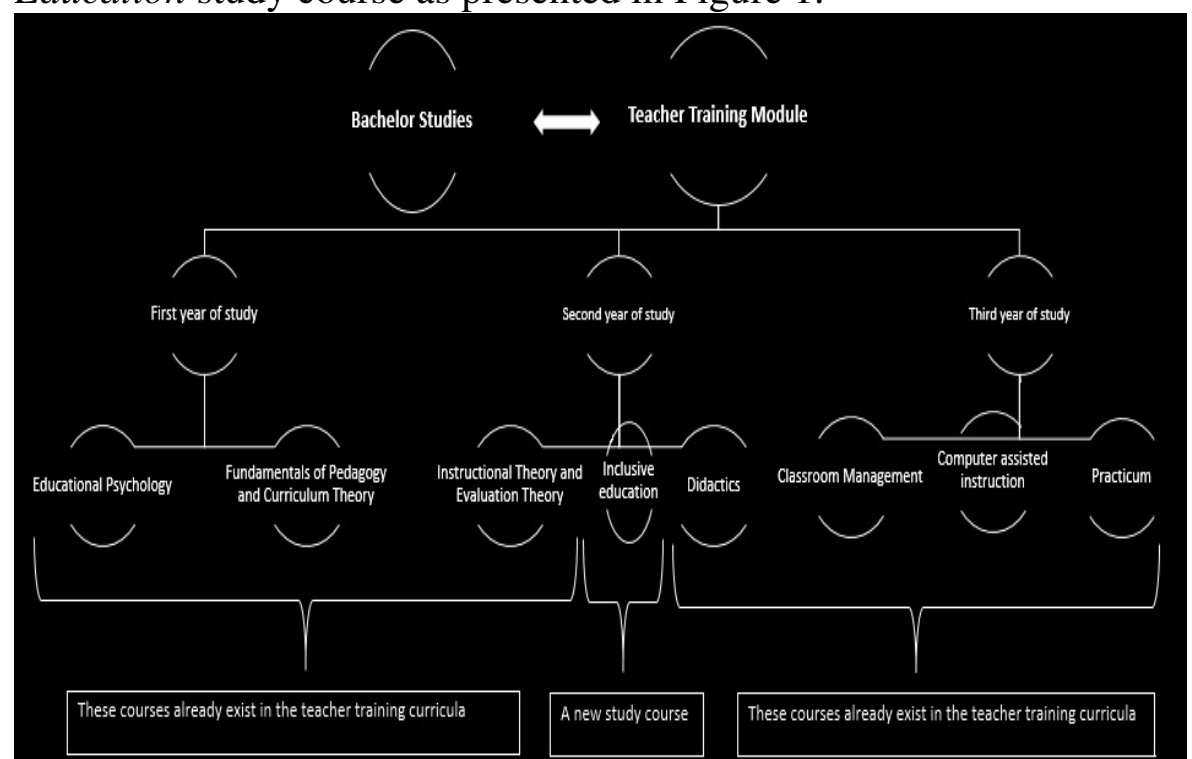

Figure 1 First proposal regarding the flexible routes into the initial teaching training

The main advantage is that all future teachers, regardless of their field of study and from an early stage into the teacher training career, have the possibility to acquire knowledge regarding inclusive education and they will be able to develop positive attitude towards inclusiveness. As a main limitation is the fact that the insertion of another study discipline will enhance the number of study hours within the third year of study. 
The second proposalstargets the implementation of a module that will be different from the existing one presented above. This module will focus only on inclusive education and is presented in Figure 2.

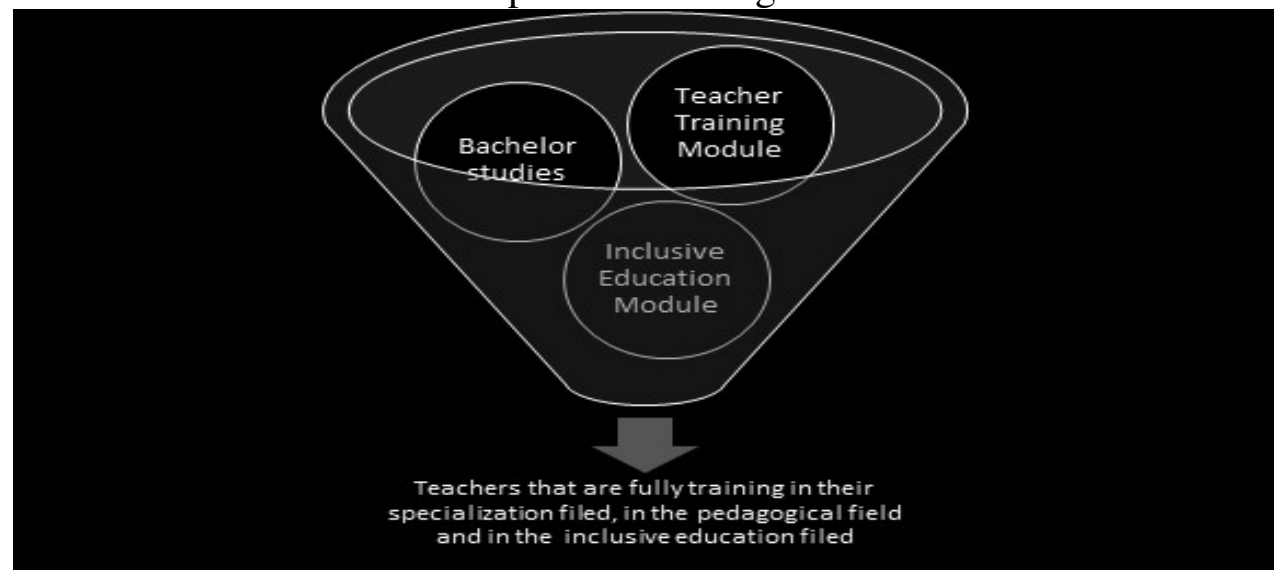

Figure 2 Second proposal regarding the flexible routes into the initial teaching training

In comparison with the first proposal, the second one implies the allocation of a larger number of study subjects which could cover the inclusive education domain generating a greater knowledge within the inclusive education field. The proposal implies that students must go through both a teacher training module and at the same time they must follow this distinctive module of inclusive education. The inclusive module does not only imply gathering knowledge into the inclusive education filed, but it can offer future students a practical perspective, the practicum that can be made in mainstream schools, but also on special schools. This Inclusive module can have a duration of one year and can be run in parallel with the classical one, giving future students to possibility to study courses such as: Concepts and Contexts of Special and Inclusive Education and Social, Emotional and Behavioral Development in Children with Speech. The main disadvantage is related to the time allocated for this module. Students who want to peruse the teaching career have to go not only through the three-year general teacher training module, but they also must go, in parallel, with the module that will allow them to get a proper training into the issues of inclusiveness. This means an overload of students' curricula, that students may not be ready to embrace.

A last proposal is in accordance with the new Romanian National Education Law 1/2011 that claims that the initial teacher training cannot be carried out through the TTDs, but it has to be done only at a master level, embracing the consecutive model into the initial teacher training. Starting from this new settlement of the Education Law, is presented the third flexible 
routeregarding the initial teacher training that targets the implementation of a new didactic master focused on inclusive education. This third route is presented in Figure 3.

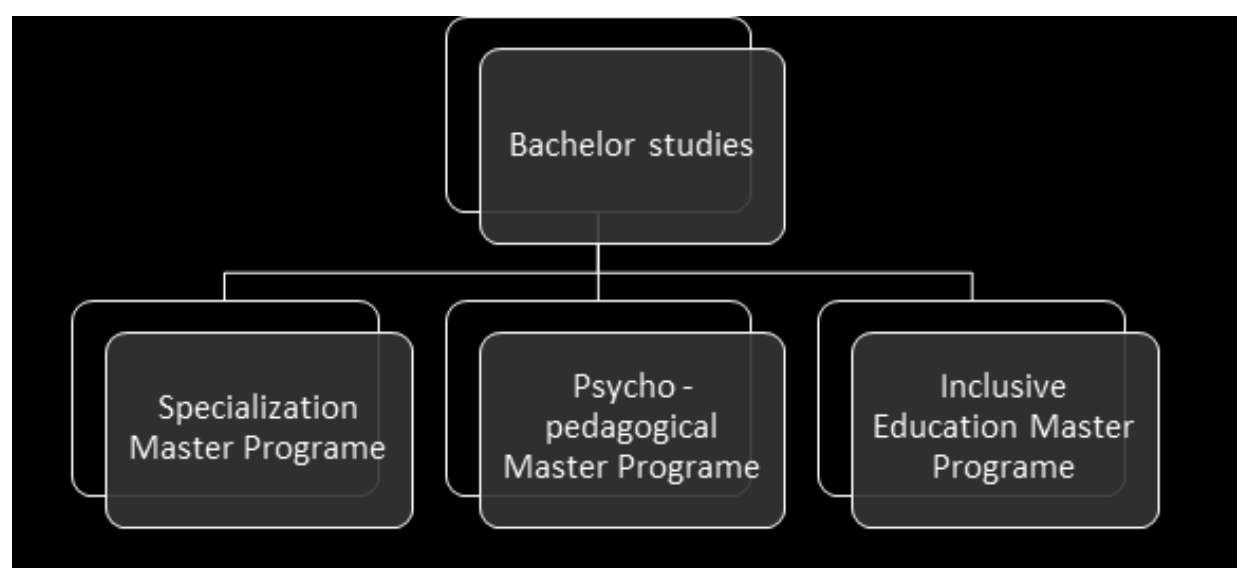

Figure 3 Third proposal regarding the flexible routes into the initial teaching training

The advantage of this proposal is that it allows to train specialists at the highest standards, throughout a master programme. The duration of these master, according to the Bologna process can be two years, meanwhile future teachers will have the opportunity to improve their professional practice through greater knowledge, skills, understanding and awareness related to inclusive education. A main limitation of this proposal is the fact that after graduation students cannot be obliged to follow this specific master programme. They have a variety of masters from where to choose, as presented in figure 3. So, future teachers can choose to follow a master programme related to their specialization (mathematics, physics, languages, chemistry, etc.), or they can follow a master that focuses on psiho pedagogical master programme (school counselling, train the trainer, early childhood care and development) or a master on inclusiveness. That means that not all the teachers can benefit from a proper training related to inclusive education, therefore not all teachers are going to be ready to face inclusion in the classroom.

All the three alternative routes presented above are required to obtain accreditation from both the Ministry of Education and the Romanian National Qualifications Authority (ANC). The providers of this type of training courses can be higher education institutions. 


\subsection{Flexible routes regarding the teachers`continuing professional developmentin the field of inclusive education}

While presenting the flexible routes for the Continuing Professional Development (CPD) it should be presented the importance that this process has significant and positive impact on the teaching career, especially having a positive impact on school performance by developing teachers' competence in teaching transversal competences and heterogeneous classes, and collaborating with both peers or parents (Angrist \& Lavy, 2001; Darling-Hammond et al., 2005; Rivkin, Hanushek, Kain, 2005; Rockoff, 2004)

\subsubsection{CPD Progressive Route 1 - attending CPD training programs} accredited by the National Qualifications Authority (ANC) with the aim of extending transversal competences.

The European Committee encourages the participation in the life-long education courses, meanwhile emphasizing its importance in the adults' professional development. According art. 328 from the Romanian Educational Law "The permanent education represents the overall teaching activities performed by each person during his lifetime in formal, non-formal and informal context, for training and developing competences in a multiple perspective: personal, civil, social or occupational [..] The life-long learning focuses on training and developing key competences and specific competences for an area of activity and also qualifications." (Romania Law of Education, 1/2011 Art. 328)

From the above mentioned it can be concluded that of the legislation points out that CPD is an essential pillar in supporting the development of a qualitative education system. However, European statistics show concerns about the Romanian situation regarding the participation of adults in the CPD courses. According to a study performed by Eurydice, the Northern countries, the Netherlands and the United Kingdom, have already achieved the European target for 2020, meanwhile, Austria and Slovenia are close to fulfilling the target, while the adults' participation in education and training is far behind the EU indicator when it comes to Romania - where less than $2 \%$ of the adults people participate in education and training. (Eurydice, 2011)

For this training route to be considered feasible, it must be mentioned that going through CPD courses means teachers will earn credits, because within the Romanian education system it is compulsory that all teachers must obtain at least 90 ECTS over a period of 5 years. 
3.3.2 Progressive Route 2 - participating at international mobility programs: Erasmus + programmes, community projects, bilateral and multilateral institutional projects, international projects.

The participation of teachers in several training courses through international mobility aims to provide learning opportunities by sharing knowledge and skills and also provides teachers with the opportunity to learn from the experience of the partner institutions or other colleagues from other countries. At the end of the mobility program, teachers can obtain a certificate (for short term programs) or a study document that certifies a level of qualification (for long-term programs). The participation of the teachers in the mobility programs is recognized according to the existing normative settlements for the teachers' continuous training courses and for their promotion in teaching career.

3.3.3 Progressive Route 3 - regular training programs: programs accredited by $A N C$

According to the Romanian order no. 4796 / 19.10.2001 Art. 2. (1) it is stipulated that the teacher training programs' is structured on modules and the minimum standard for teacher training program is of 90 ECTS.

Therefore, each teacher enrolled in a training program must accumulate, by the end of the statutory period of 5 years, a minimum of 90 ECTS from different training providers who can offer not only training programs as a whole, but also parts of them, module that added up make a total of 90 ECTS. Additional ECTS (those exceeding the minimum number of 90) will be considered a premise for obtaining facilities in future teaching career progression. The suppliers of the training programs can be either the higher education institutions through the Teacher Training Departments and through various teaching masters, the Teacher Training Houses (TTHs) or different NGOs with activities in the field of education, whose training programs have been approved by the National Centre for the Training of School Education (NCTSE).

All three alternative CPD routes target short programs, basically modular programs, that are offer by either higher education institutions, by different NGOs whose course are accredited by the Ministry of Education, by the Institute of Education Sciences, or by the National Agency for Community programs in Education and vocational training (ANPCDEFP).

\section{Conclusions}

It is necessary to implement a system of initial and continuing training that meets the current requirements of future teachers, regardless of their specialization and offer them a proper start into the teaching career. Moreover, teachers` have to go through a series of training courses in order 
to prepare them to face inclusion in the classroom, acquiring special set of skills o that they will be able to work in an inclusive learning environment.

The need to incorporate these courses is supported by the school's reality seen through the eyes of national statistics. These statistics reveal a reality, namely that the presence of students with special needs is a constant in Romanian schools.

The regulation of the initial training curriculum should be based on a system that is centrally governed by the Ministry of Education and the National Authority for Qualifications. We consider necessary to keep the existing Bologna systems of initial teacher training that is implemented at national level and international level, but a greater importance should be given to the inserting a study course that prepares teachers for the inclusive education.

\section{References}

Angrist, J.D. \& Lavy, V. (2001). Does Teacher Training Affect Pupil Learning? Evidence from Matched Comparisons in Jerusalem Public Schools. Journal of Labor Economics, Vol. 19(2), pp. 343-369.

COM. (2007a). Teachers need good education too! The Commission proposes to improve the quality of teacher education in the European Union, IP/07/1210, Bruxelles, 6 august 2007

COM. (2007b). Communication from the Commission to the Council and the European Parliament of 3 August 2007 'Improving the Quality of Teacher Education' [COM(2007) 392 final - Not published in the Official Journal].

Darling Hammond, L., Holtzman, D.J., et al. (2005). Does teacher preparation matter? Evidence about teacher certification, Teach for America, and teacher effectiveness. Education Policy Analysis Archives, 13(42) 16-17, 20.

Emergency Ordinance no 3841/2012, Available at: http://www.dreptonline.ro/legislatie/oug_36_2012_masuri_reorganizare_m odificare_legea_monitorul_oficial.php, Retrieved on: 19.03.2016

Iucu, R., Păcurari, O. (2001). Formarea inițială şi continuă a cadrelor didcatice - introducerea sistemului de credite transferabile:evoluţii şi perspective, (Romanian), Editura Humanitas Educational, București

Marin, E. (2014). Are Today's General Education Teachers Prepared to Face Inclusion in the Classroom?. Procedia-Social and Behavioral Sciences, 142, 702-707.

Order no. 4796 / 19.10.2001 Art. 2., Available at: http://www.edu.ro/index.php?module=uploads \&func=download \&fileId=6 61, Retrieved on 19.03.2016

Paun, E. (2002). Profesionalizarea carierei didactice, în „Standarde profesionale pentru profesia didactica", Consiliul National pentru Pregatirea Profesorilor, (Romanian), Bucuresti 
Potolea,D., Toma, S. (2013). Standards for the teaching profession/ Standarde pentru profesia didactică, (Romanian), Available at: http://www.congresuleducatiei.ro/ckfinder/userfiles/files/SToma_\%20DPot olea.pdf,

Rivkin, S.G., Hanushek, E.A. \& Kain, J.F. (2005). Teachers, Schools, and Academic Achievement. Econometrica, Vol. 73, No. 2, pp. 417-458 http://edpro.stanford.edu/Hanushek/admin/pages/files/uploads/ teachers.econometrica.pdf.

Rockoff, J.E. (2004). The Impact of Individual Teachers on Student Achievement: Evidence from Panel Data. AEA Papers and Proceedings, May 2004.

Romanian Law of Education 1/2011, Available at: http://keszei.chem.elte.hu/Bologna/Romania_Law_of_National_Education. pdf, Retrieved on 19. 03. 2016 